\title{
Disseminated Mycobacterium simiae infection in a patient with adult-onset immunodeficiency due to anti-interferon- gamma antibodies - a case report
}

B. S. D. P. Keragala', C. N. Gunasekera', P. D. Yesudian², Chandima Guruge', B. S. Dissanayaka', D. P. Liyanagama', G. I. M. Jinadasa', S. R. Constantine ${ }^{1}$ and H. M. M. T. B. Herath ${ }^{1 *}$

\begin{abstract}
Background: Mycobacterial species other than Mycobacterium tuberculosis and Mycobacterium leprae are generally free-living organisms and Mycobacterium simiae is one of the slowest growing Non-tuberculous mycobacteria. This is the first case report of Mycobacterium simiae infection in Sri Lanka and only very few cases with extrapulmonary manifestation reported in the literature.

Case presentation: A 24-year-old, previously healthy Sri Lankan male presented with generalized lymphadenopathy with discharging sinuses, evening pyrexia, weight loss, poor appetite and splenomegaly. Lymph node biopsies showed sheets of macrophages packed with organisms in the absence of granulomata. Ziehl Neelsen, Wade Fite and Giemsa stains revealed numerous red coloured acid-fast bacilli within foamy histiocytes. Slit skin smear for leprosy was negative and tuberculosis, fungal and bacterial cultures of the lymph node and bone marrow did not reveal any growth. Later he developed watery diarrhea and colonoscopy revealed multiple small polyps and ulcers throughout the colon extending up to the ileum, Which was confirmed to be due to cytomegalovirus confirmed by PCR and successfully treated with ganciclovir. Positron emission tomography scan guided biopsies of the gut and lymph nodes confirmed presence of mycobacterial spindle cell pseudo-tumours and PCR assays revealed positive HSP65. The culture grew Mycobacterium Simiae. Flow cytometry analysis on patient's blood showed extremely low T and B cell counts and immunofixation revealed low immunoglobulin levels. His condition was later diagnosed as adult onset immunodeficiency due to anti- interferon - gamma autoantibodies. He was initially commenced on empirical anti-TB treatment with atypical mycobacterial coverage. He is currently on a combination of daily clarithromycin, ciprofloxacin, linezolid with monthly $2 \mathrm{~g} / \mathrm{kg} / \mathrm{intravenous} \mathrm{immunoglobulin} \mathrm{to} \mathrm{which,} \mathrm{he} \mathrm{had} \mathrm{a}$ remarkable clinical response with complete resolution of lymphadenopathy and healing of sinuses.
\end{abstract}

Conclusions: This infection is considered to be restricted to certain geographic areas such as mainly Iran, Cuba, Israel and Arizona and this is the first case report from Sri lanka. Even though the infection is mostly seen in the elderly patients, our patient was only 24 years old. In the literature pulmonary involvement was common presentation, but in this case the patient had generalized lymphadenopathy and colonic involvement without pulmonary involvement.

Keywords: Disseminated Mycobacterium simiae infection, Adult-onset immunodeficiency due to anti-interferon-gamma antibodies, Sri lanka, Case report

\footnotetext{
*Correspondence: Tharukaherath11@gmail.com

${ }^{1}$ National Hospital of Sri Lanka, Colombo, Sri Lanka

Full list of author information is available at the end of the article
}

C C The Author(s). 2020 Open Access This article is licensed under a Creative Commons Attribution 4.0 International License, which permits use, sharing, adaptation, distribution and reproduction in any medium or format, as long as you give appropriate credit to the original author(s) and the source, provide a link to the Creative Commons licence, and indicate if changes were made. The images or other third party material in this article are included in the article's Creative Commons licence, unless indicated otherwise in a credit line to the material. If material is not included in the article's Creative Commons licence and your intended use is not permitted by statutory regulation or exceeds the permitted use, you will need to obtain permission directly from the copyright holder. To view a copy of this licence, visit http://creativecommons.org/licenses/by/4.0/. The Creative Commons Public Domain Dedication waiver (http://creativecommons.org/publicdomain/zero/1.0/) applies to the data made available in this article, unless otherwise stated in a credit line to the data. 


\section{Background}

Mycobacterial species other than Mycobacterium tuberculosis and Mycobacterium leprae are generally freeliving organisms that are found in water, soil, domestic and wild animals, milk, and food and has been noted in environment as viable by Reverse transcription polymerase chain reaction $[1,2]$.

Mycobacterium simiae is one of the slowest growing Non-tuberculous mycobacteria (NTM) which was initially identified from rhesus monkeys in 1965 [3] and was reported in the Southern United States, Cuba, Palestine, Iran, Israel, Turkey, and Japan [4]. Here we report a case of a young man who initially presented with constitutional symptoms like lymphadenopathy, splenomegaly and later intestinal lesions and was diagnosed to be infected with Mycobacterium simiae. He was also diagnosed with adult onset immunodeficiency with antiinterferon - gamma autoantibodies. Adult onset immunodeficiency with anti-interferon-gamma autoantibodies is a rare acquired condition where high titres of neutralizing anti-Interferon gamma antibodies affecting Interferon gamma-Interleukin 12 pathways are detected. Typical cases are young, previously healthy individuals of Asian origin presenting with lymphadenopathy (cervical or generalized), constitutional symptoms and reactive skin changes due to disseminated non-tuberculous mycobacterial infections. This is the first case report of Mycobacterium simiae infection in Sri Lanka and only very few cases of extrapulmonary cases reported in the literature.

\section{Case presentation}

A 24-year-old, previously healthy Sri Lankan male was referred for evaluation of generalized lymphadenopathy. $\mathrm{He}$ also had evening pyrexia, weight loss, poor appetite and splenomegaly. Cervical and axillary lymph nodes later developed in to discharging sinuses (Fig. 1). Repeated lymph node biopsies showed sheets of macrophages packed with organisms in the absence of granulomata (Fig. 2). Ziehl Neelsen (Fig. 3), Wade Fite (Fig. 4) and Giemsa stains (Fig. 5) revealed numerous red coloured acid-fast bacilli within foamy histiocytes. Grocott stain (Fig. 6) was weakly positive. However Slit skin smear for leprosy was negative and tuberculosis (TB), fungal and bacterial cultures of the lymph node and bone marrow did not reveal any growth. Tuberculosis interferon gamma release assays and TB Polymerase chain reaction (PCR) were also negative. Computerized tomography (CT) scan showed splenomegaly and multiple paraaortic and inguinal lymphadenopathy. Antinuclear antibodies were negative and HIV (human immunodeficiency virus) 1 and 2 antibodies and P24 antigen were 2 times negative in 3 months apart. Due to the unusual presentation, the patient was investigated for possible immunodeficiency with flowcytometry analysis, which showed extremely low $\mathrm{T}$ and $\mathrm{B}$ cell

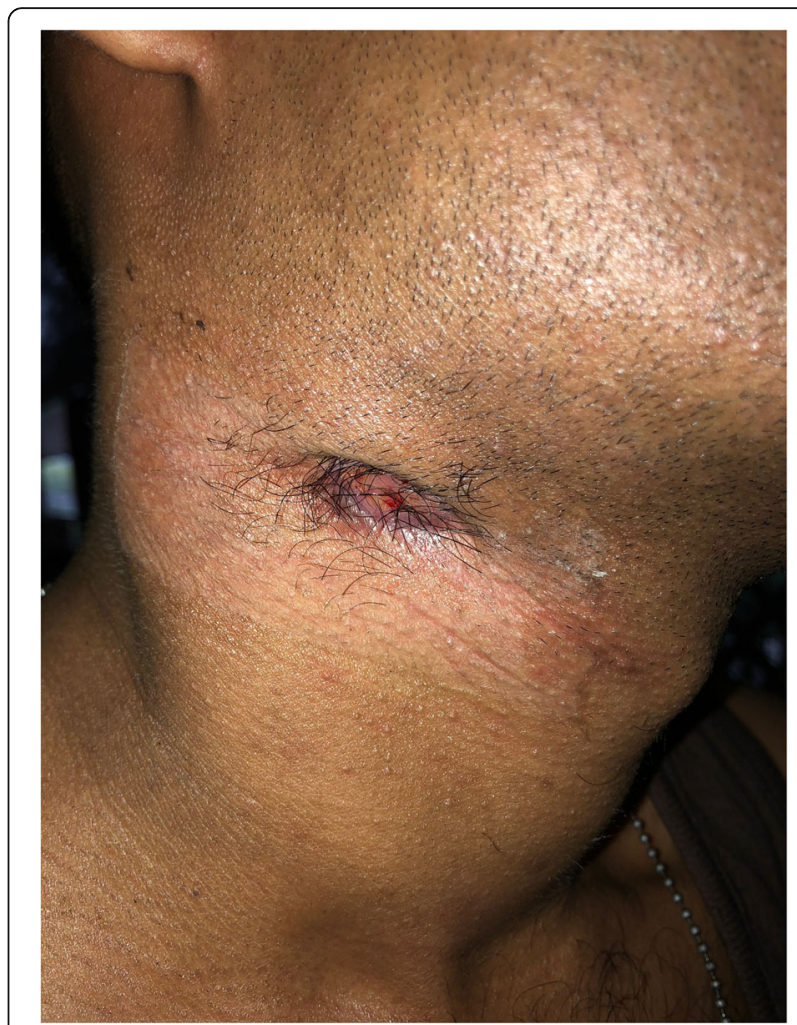

Fig. 1 Cervical and axillary lymph nodes later developed in to discharging sinuses

counts and immunofixation revealed low immunoglobulin levels (Table 1).

As the condition deteriorated, he was commenced on empirical anti-TB treatment (isoniazid, rifampicin, pyridoxime and ethambutol) with atypical mycobacterial coverage (intravenous amikacin and imipenum for 6 weeks with oral clarithromycin and ciprofloxacin). Although he responded initially, 8 months into treatment

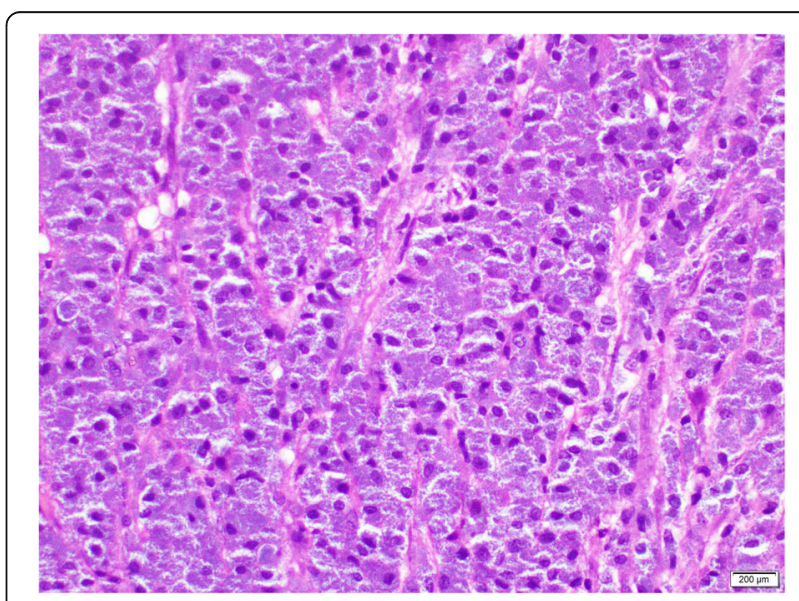

Fig. 2 Repeated lymph node biopsies showing sheets of macrophages packed with organisms in the absence of granulomata 


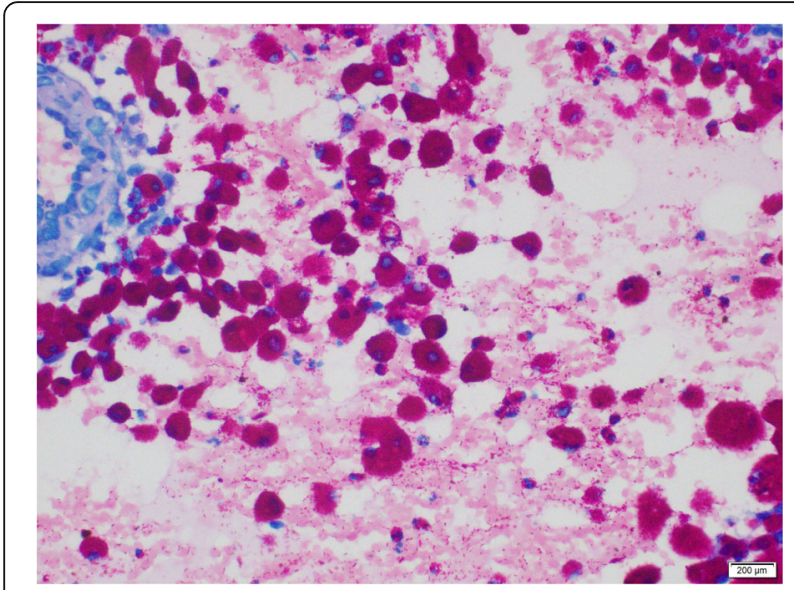

Fig. 3 Ziehl Neelsen revealing numerous red coloured acid-fast bacilli within foamy histiocytes

he relapsed with recurrence of lymphadenopathy and watery diarrhoea. Colonoscopy revealed multiple small polyps and ulcers throughout the colon extending up to the ileum (Fig. 7), which was confirmed to be cytomegalovirus by PCR and successfully treated with ganciclovir. Positron emission tomography scan guided biopsies of the gut and lymph nodes confirmed mycobacterial spindle cell pseudo-tumours. Then we sequenced PCR products from the lymph node biopsies and IS6110 PCR assay was negative and and HSP65 PCR assay was positive. IS6110 is uniquely found in Mycobacterium tuberculosis complex [5] and hsp65 is positive in Mycobacterium tuberculosis complex and nontuberculosis mycobacteria [6]. Later the culture grew Mycobacterium Simiae. After seeking advice from an expert centre, his condition was later diagnosed as adult onset immunodeficiency due to anti- interferon gamma autoantibodies. Anti- interferon - gamma autoantibodies were measured by Enzyme-Linked

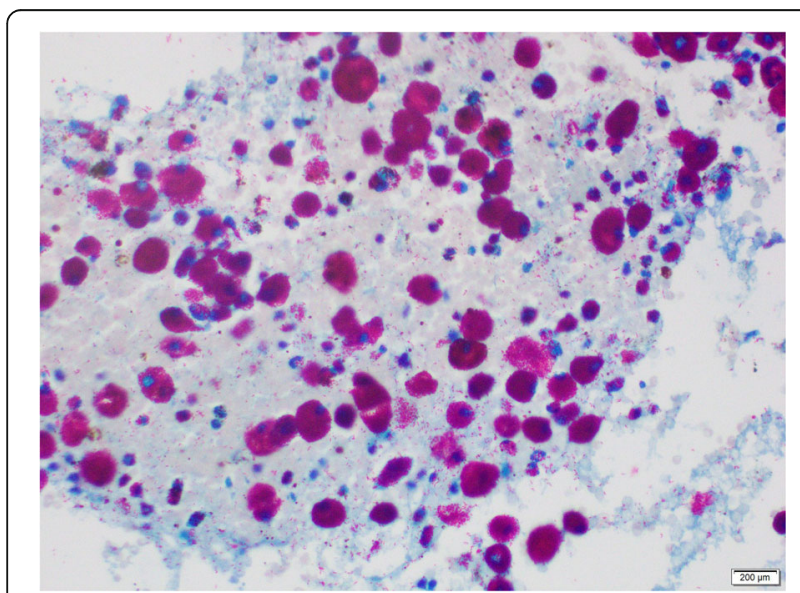

Fig. 4 Wade Fite revealed numerous red coloured acid-fast bacilli within foamy histiocytes

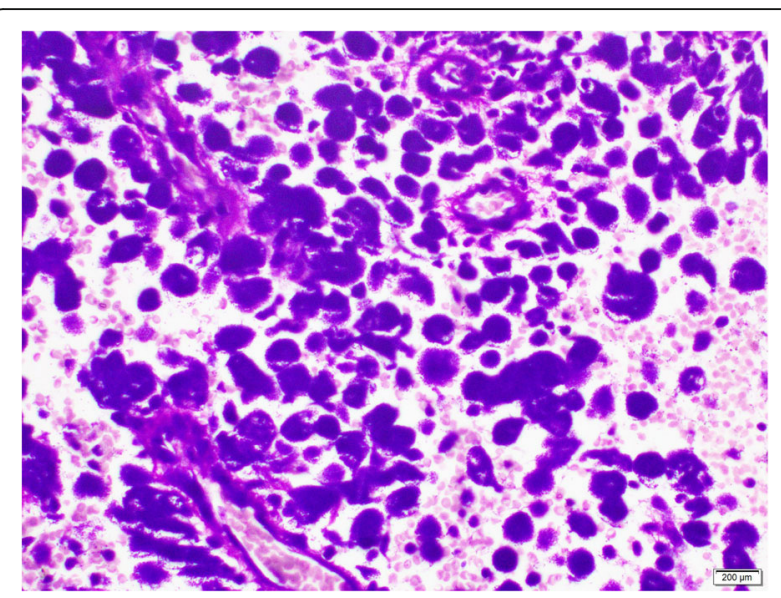

Fig. 5 Giemsa stains revealed numerous red coloured acid-fast bacilli within foamy histiocytes

Immunosorbent Assay (ELISA) method after serially diluting samples from the patient and control and was positive was positive at 1:30000. He is currently on a combination of daily clarithromycin, ciprofloxacin, linezolid with monthly $2 \mathrm{~g} / \mathrm{kg} /$ intravenous immunoglobulin (IVIG) treatment, to which, he had a remarkable clinical response with complete resolution of lymphadenopathy and healing of sinuses (Fig. 8). The immunoglobulin levels returned to normal levels, except Ig A fraction and CD4 counts improved (Table 2). Immuno suppressants or biologics (Rituximab) were not considered due to the fear of dissemination of infection. Time line is given in the Fig. 9.

\section{Discussion and conclusions}

$M$. simiae is a frequent colonizer of the lung and is not usually pathogenic in immunocompetent people. This infection seems to be restricted to certain geographic areas such as mainly Iran, Cuba, Israel and Arizona most probably due to common environmental factors including temperature and

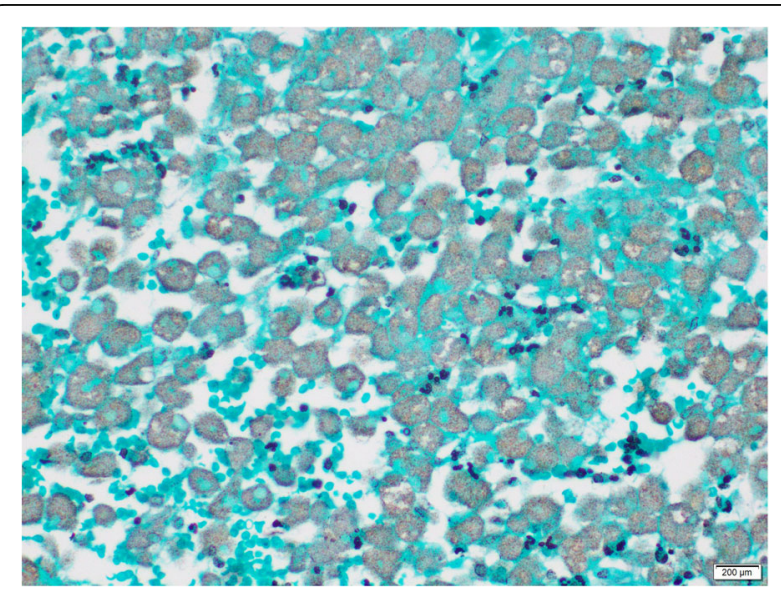

Fig. 6 Grocott stain showing weak positivity 
Table 1 Low T and B cell counts and low immunoglobulin levels

\begin{tabular}{lll}
\hline Investigation & Result & Reference value \\
\hline CD4 lymphocyte absolute counts & 45 cells/mm3 & $300-1400$ \\
CD8 lymphocyte absolute counts & 21 cells $/ \mathrm{mm} 3$ & $200-900$ \\
CD4 / CD8 ratio & 2.95 & $0.7-2.5$ \\
CD3 lymphocyte absolute counts & 72 cells $/ \mathrm{mm3}$ & $700-2100$ \\
CD19 lymphocyte absolute counts & 43 cells $/ \mathrm{mm3}$ & $100-500$ \\
Ig E level & $13.9 \mathrm{IU} / \mathrm{mL}$ & $20.4(95 \%$ ile $=87)$ \\
IgA level & $56.0 \mathrm{mg} / \mathrm{dL}$ & $70-400$ \\
IgG level & $670 \mathrm{mg} / \mathrm{dL}$ & $700-1600$ \\
IgM level & $70.5 \mathrm{mg} / \mathrm{dL}$ & $40-230$ \\
\hline
\end{tabular}

humidity $[7,8]$ However M. simiae has also been isolated in in many distant countries as well [3]. In a recent study from India, M. simiae bacilli were closely associated with M.leprae and other pathogenic non-tuberculous mycobacteria in leprosy endemic area due to water and soil sources [9]. The infection is mostly seen in the elderly patients [3] and in patients with diabetes mellitus, acquired immunodeficiency syndrome (AIDS) [10], cardiovascular disease, chronic lung diseases and malignancies [11]. The average age was 61 years in one case series. However several case reports describe lymphadenopathy in children caused by $M$. simiae as well [12]. Most common symptoms reported in these patients constitutional symptoms with sweating, weight loss, lowgrade fever and pulmonary symptoms such as productive cough and hemoptysis $[10,11]$ Only very few cases of extrapulmonary $M$. simiae infections are found the literature including vertebral osteomyelitis [13], localized lymphadenitis [14], genitourinary tract infection [15, 16] skin lesions [14], parotid gland infection [13] and nervous system infection [17]. In our patient the main presenting

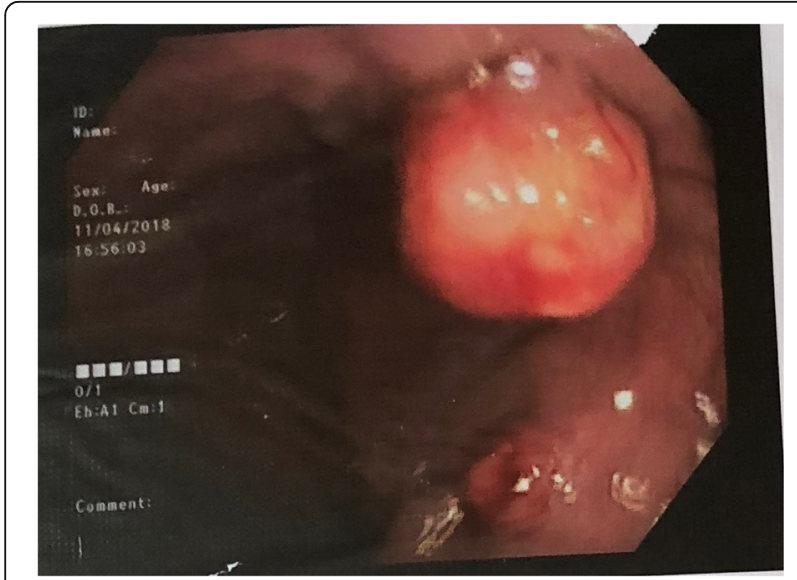

Fig. 7 Colonoscopy revealed multiple small polyps and ulcers throughout the colon extending up to the ileum

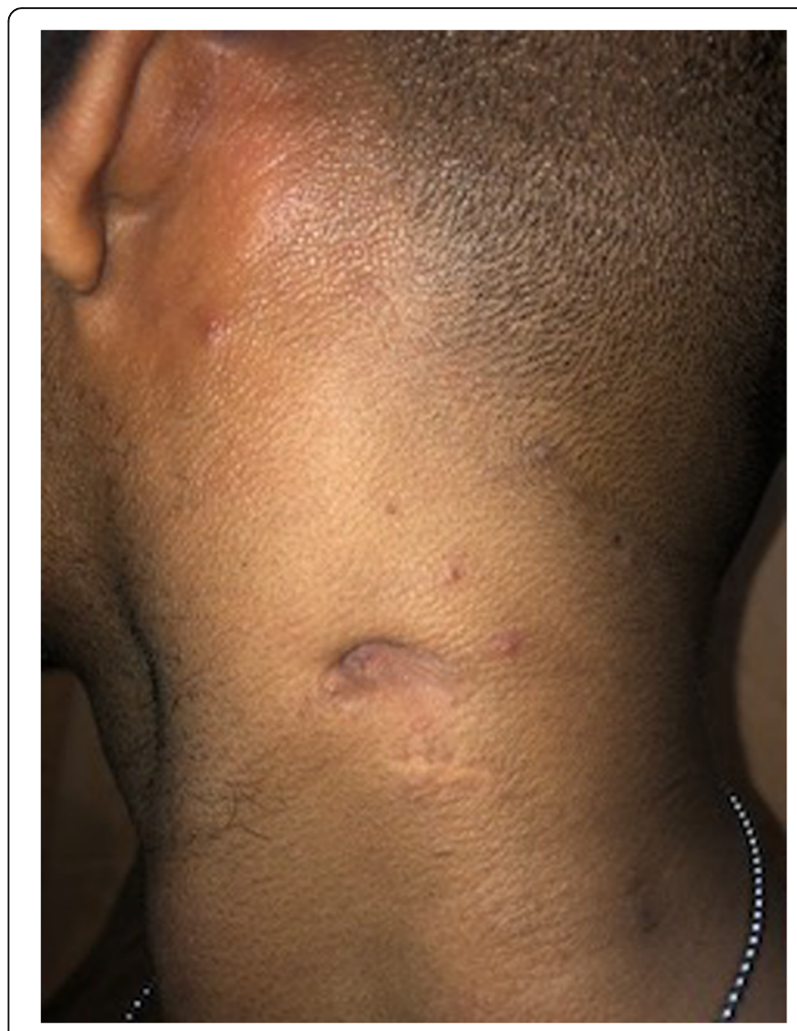

Fig. 8 Complete resolution of lymphadenopathy and healing of sinuses

complains were fever, constitutionals symptoms with generalized lymphadenopathy and splenomegaly. Later he developed blood and mucous diarrhea due to colonic involvement. Interestingly our patient did not have respiratory system involvement and high resolution CT of the chest and bronchoalveloar larvage were normal. The histopathological findings in $M$. simiae infection can be classical tuberculous-like granulomas with varying degrees of necrosis or non-necrotic granulomas [18]. In our patient biopsy of the lymph node revealed large nodular collection of epitheliod histiocytes and scatted small collections of foamy histiocytes. No granulomas or caseous necrosis was seen and both Wade- Fite stain and Ziehl - Neelson stain revealed numorous red coloured acid-fast bacilli filling the cytoplasm of foamy histiocytes. Even though interferon-

Table $2 \mathrm{~T}$ and B cell counts and low immunoglobulin levels after treatment

\begin{tabular}{lll}
\hline Investigation & Result & Reference range \\
\hline CD4 lymphocyte absolute counts & 160 cells/mm3 & $500-1500$ \\
CD8 lymphocyte absolute counts & 54 cells/mm3 & $200-900$ \\
Ig E level & $13.9 \mathrm{IU} / \mathrm{mL}$ & 20.4 \\
IgA level & $57.0 \mathrm{mg} / \mathrm{dL}$ & $70-400$ \\
IgG level & $1079 \mathrm{mg} / \mathrm{dL}$ & $700-1600$ \\
IgM level & $84 \mathrm{mg} / \mathrm{dL}$ & $40-230$ \\
\hline
\end{tabular}




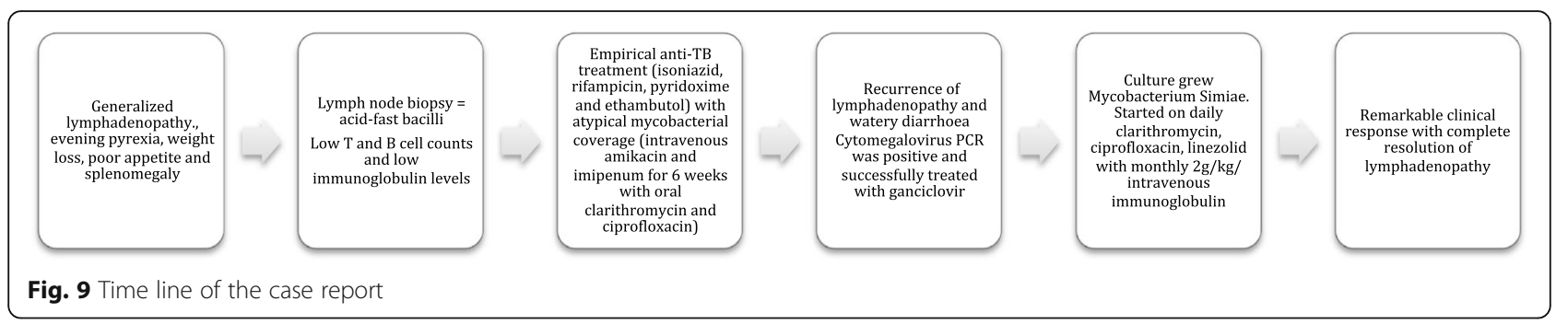

gamma release assays was negative in our patient in many patients with disseminated non-tuberculous mycobacteria infection and neutralizing anti- interferon-gamma autoantibodies, interferon-gamma release assays were indeterminate because of extremely low or undetectable interferongamma levels in the mitogen tubes [19].

No firm conclusions regarding the best regimen and duration of treatment is available due to limited case reports and series. In our patient we initially started anti tuberculosis treatment (Isoniacid, ethambutol, pyrazinamide and rifampicin). Later he was also given intravenous amikacin and imipenum for 6 weeks with oral clarithromycin and ciprofloxacin. A resent retrospective study suggested clarithromycin in different combinations with cotrimoxazole, moxifloxacin, and amikacin for a duration of 6 to 24 months [11]. Van Ingen J et al., suggested clarithromycin combined with moxifloxacin and another susceptible drug (e.g. clofazimine, Trimethoprim (TMP) / Sulfamethoxazole (SMX), amikacin, streptomycin) [20]. Adding clofazimine to amikacin can have synergistic activity against $M$. simiae [21].Another study suggested a combination of four-drug regimen containing clarithromycin, ethambutol, rifabutin and streptomycin [22]. However because of variable susceptibly profile of this pathogen in different geographic locations susceptibility testing is important before initiating therapy [11]. Unfortunately drug susceptibility testing was not available in our setup. We planned out our treatment and follow up depending on the available literature in treating this infection. Our patient initially responded to anti-TB treatment with amikacin, clarithromycin and ciprofloxacin but later relapsed may be due to development of resistance. However adding linezolid and immunoglobulins led to a remarkable clinical improvement. Linezolid was active against $100 \%$ of isolates of M.simiae in one study [23].

Adult-onset immunodeficiency with anti-interferongamma autoantibodies is an immunodeficiency disorder, which is associated with susceptibility to disseminated infections such as non-tuberculous mycobacteria, nontyphoidal salmonella, cytomegalovirus, Penicillium marneffei, and varicella zoster virus [24, 25] Our patient initially got a mycobacterial infection and later developed cytomegaloviral infection. This needs to be considered in
HIV negative adult patients with unknown immunodeficiency and severe, persistent or recurrent infections especially of Asian origin and having reactive skin lesions and autoimmune endocrinopathy. Unusual presentations and atypical staining patterns warrant investigation for immunodeficiency status and associated infections with atypical organisms. Though the CD4 count was extremely low in our patient, which was supportive of idiopathic CD4 lymphocytopenia, it is uncommon to have a good CD4 to CD8 ratio $>0.8$. Hence, adult onset immunodeficiency with anti- interferon - gamma autoantibodies was suspected. However in most patients with adult-onset immunodeficiency due to anti-inferferongamma antibodies have normal CD 4 counts [26]. The initial low counts would have been due on going sepsis and after the infection is controlled the counts improved. Currently there is no standard treatment for adult onset immunodeficiency with anti-interferongamma autoantibodies but long-term antimicrobial therapy and rituximab have been used with variable success [19]. Immunosuppressants were not considered in our patient due to the fear of dissemination of infection. He remains in remission with the use of monthly $2 \mathrm{~g} / \mathrm{kg}$ IVIG, clarithromycin, ciprofloxacin and linezolid. Even though IVIG was originally used as a replacement therapy for primary and secondary immunodeficiency diseases characterized by the absence or deficiency of antibody production there are other clinical benefits of IVIG treatment. Many of these other uses because of the anti-inflammatory and immunomodulatory effects of IVIG [27]. IVIG was also used in a patient with antiinterferon - gamma autoantibodies to suppress the production of autoantibodies but had had little efficacy in suppressing the production of autoantibodies in vitro testing [28]. It has been suggested that IVIG may be an alternative option in these patients due to its immunomodulatory effect [29]. In our patient, the affectivity of IVIG was subsequently was evidenced objectively by the improvement in CD4 cell count and immunoglobulin levels and subjectively by the clinical improvement.

This case in interesting because this is the first case report of M.simiae from Sri lanka and even though the infection is mostly seen in the elderly patients, our patient was only 24 years old. In the literature pulmonary involvement 
was the comment presentation, but in this case the patient had generalized lymphadenopathy and colonic involvement without pulmonary involvement. This case also highlights the importance of looking for an underlying immunodeficiency syndrome in patients with atypical infections. Drug susceptibility testing for atypical infections will be useful because of development of resistance.

\section{Abbreviations}

NTM: Non-tuberculous mycobacteria; TB: Tuberculosis; IVIG: Intravenous immunoglobulin; AIDS: Acquired immunodeficiency syndrome

\section{Acknowledgements}

This case was presented at the Abstracts for the British Association of Dermatologists 99th Annual Meeting, Liverpool, U.K., 2-4 July 2019, https:// onlinelibrary.wiley.com/doi/abs/10.1111/bjd.17894.

'Abstracts for the British Association of Dermatologists 99th Annual Meeting, Liverpool, U.K., 2-4 July 2019.', 181 Suppl 1 (2019), 3-196 <https://doi.org/10. 1111/bjd.18067>

\section{Authors' contributions}

BSDPK, CNG, PDY, CG,BSD and DPL were involved in the diagnosis and management of the patent. HMMTBH, PDY, CG,BSD, DPL, GIMJ and SRC were involved in acquisition of patient's data. HMMTBH, PDY, CG,BSD, DPL, GIMJ and SRC did the literature survey. BSDPK, CNG and HMMTBH drafted and corrected the manuscript. All the authors read and approved the manuscript.

\section{Funding}

No source of funding.

\section{Availability of data and materials}

The datasets supporting the conclusions of this article are included within the article.

\section{Ethics approval and consent to participate}

Not applicable.

\section{Consent for publication}

Written informed consent was obtained from the patient for publication of this case report and any accompanying images. A copy of the written consent is available for review by the Editor-in-Chief of this journal.

\section{Competing interests}

The authors declare that they have no competing interests.

\section{Author details}

${ }^{1}$ National Hospital of Sri Lanka, Colombo, Sri Lanka. ${ }^{2}$ Wrexham Maelor Hospital, Wrexham, UK.

Received: 27 July 2019 Accepted: 20 March 2020

Published online: 01 April 2020

\section{References}

1. Gruft H, Falkinham JO, Parker BC. Recent experience in the epidemiology of disease caused by atypical mycobacteria. Rev Infect Dis. 1981;3(5):990-6.

2. Turankar RP, Lavania M, Singh M, Siva Sai KSR, Jadhav RS. Dynamics of Mycobacterium leprae transmission in environmental context: deciphering the role of environment as a potential reservoir. Infect Genet Evol. 2012; 12(1):121-6. https://doi.org/10.1016/j.meegid.2011.10.023.

3. van Ingen J, Boeree MJ, Dekhuijzen PNR, van Soolingen D. Clinical relevance of Mycobacterium simiae in pulmonary samples. Eur Respir J. 2008;31(1): 106-9. https://doi.org/10.1183/09031936.00076107.

4. Hashemi-Shahraki A, Darban-Sarokhalil D, Heidarieh P, et al. Mycobacterium simiae: a possible emerging pathogen in Iran. Jpn J Infect Dis. 2013;66(6):475-9.

5. Rodríguez JC, Royo G, Rodríguez-Valera F. Application of four molecular techniques for typing outbreak-associated Mycobacterium tuberculosis strains. APMIS. 2000;108(3):231-6. https://doi.org/10.1034/j.1600-0463. 2000.d01-49.x
6. Kim H, Kim S-H, Shim T-S, et al. Differentiation of Mycobacterium species by analysis of the heat-shock protein 65 gene (hsp65). Int J Syst Evol Microbiol. 2005;55(Pt 4):1649-56. https://doi.org/10.1099/ijs.0.63553-0.

7. Onen ZP, Karahan ZC, Akkoca Yıldız O, Karabıyıkoğlu G. Mycobacterium simiae infection in an immunocompetent patient, with DNA analyses verification. Tuberk Toraks. 2010;58(3):306-10.

8. Narang R, Narang P, Jain AP, et al. Disseminated disease caused by Mycobacterium simiae in AIDS patients: a report of three cases. Clin Microbiol Infect. 2010;16(7):912-4. https://doi.org/10.1111/j.1469-0691.2009.03021.x.

9. Turankar RP, Singh V, Gupta H, et al. Association of non-tuberculous mycobacteria with Mycobacterium leprae in environment of leprosy endemic regions in India. Infect Genet Evol. 2019;72:191-8. https://doi.org/ 10.1016/j.meegid.2018.11.010.

10. Baghaei $P$, Tabarsi $P$, Farnia $P$, et al. Pulmonary disease caused by Mycobacterium simiae in Iran's national referral center for tuberculosis. J Infect Dev Ctries. 2012;6(1):23-8.

11. Hamieh A, Tayyar R, Tabaja H, et al. Emergence of Mycobacterium simiae: A retrospective study from a tertiary care center in Lebanon. Santin M, ed. PLOS ONE. 2018;13(4):e0195390. https:/doi.org/10.1371/journal.pone.0195390.

12. Patel NC, Minifee PK, Dishop MK, Munoz FM. Mycobacterium simiae cervical Iymphadenitis. Pediatr Infect Dis J. 2007;26(4):362-3. https://doi.org/10.1097/ 01.inf.0000258614.98241.4e.

13. Piersimoni C, Scarparo C. Extrapulmonary infections associated with nontuberculous mycobacteria in immunocompetent persons. Emerging Infect Dis. 2009;15(9):1351-8-quiz1544. https://doi.org/10.3201/eid1509.081259.

14. Cruz AT, Goytia VK, Starke JR. Mycobacterium simiae complex infection in an immunocompetent child. J Clin Microbiol. 2007;45(8):2745-6. https://doi. org/10.1128/JCM.00359-07.

15. Fusco da Costa AR, Fedrizzi T, Lopes ML, et al. Characterization of 17 strains belonging to the Mycobacterium simiae complex and description of Mycobacterium paraense sp. nov. Int J Syst Evol Microbiol. 2015;65(Pt 2): 656-62. https://doi.org/10.1099/ijs.0.068395-0.

16. Rose HD, Dorff GJ, Lauwasser M, Sheth NK. Pulmonary and disseminated Mycobacterium simiae infection in Humans1,2. American Review of Respiratory Disease; 2015.

17. Balkis MM, Kattar MM, Araj GF, Kanj SS. Fatal disseminated Mycobacterium simiae infection in a non-HIV patient. Int J Infect Dis. 2009;13(5):e286-7. https://doi.org/10.1016/j.jijid.2008.10.015.

18. Marchevsky A, Damsker B, Gribetz A, Tepper S, Geller SA. The spectrum of pathology of nontuberculous mycobacterial infections in open-lung biopsy specimens. Am J Clin Pathol. 1982;78(5):695-700.

19. Wu U-I, Chuang Y-C, Sheng W-H, et al. Use of QuantiFERON-TB gold in-tube assay in screening for neutralizing anti-interferon- $\gamma$ autoantibodies in patients with disseminated nontuberculous mycobacterial infection. Clin Microbiol Infect. 2018;24(2):159-65. https://doi.org/10.1016/j.cmi.2017.06.029.

20. van Ingen J, Totten SE, Heifets LB, Boeree MJ, Daley CL. Drug susceptibility testing and pharmacokinetics question current treatment regimens in Mycobacterium simiae complex disease. Int J Antimicrob Agents. 2012;39(2): 173-6. https://doi.org/10.1016/j.jjantimicag.2011.09.019.

21. van Ingen J, Totten SE, Helstrom NK, Heifets LB, Boeree MJ, Daley CL. In VitroSynergy between Clofazimine and Amikacin in treatment of Nontuberculous mycobacterial disease. Antimicrob Agents Chemother. 2012;56(12):6324-7. https://doi.org/10.1128/AAC.01505-12.

22. Maoz C, Shitrit D, Samra Z, et al. Pulmonary Mycobacterium simiae infection: comparison with pulmonary tuberculosis. Eur J Clin Microbiol Infect Dis. 2008;27(10):945-50. https://doi.org/10.1007/s10096-008-0522-6.

23. Cavusoglu C, Soyler I, Akinci P. Activities of linezolid against nontuberculous mycobacteria. New Microbiol. 2007;30(4):411-4.

24. Pruetpongpun N, Khawcharoenporn T, Damronglerd P, et al. Disseminated Talaromyces marneffei and Mycobacterium abscessus in a Patient With Anti-Interferon- $\gamma$ Autoantibodies. Open Forum Infect Dis. 2016;3(2):ofw093. https://doi.org/10.1093/ofid/ofw093.

25. Chan JF-W, Trendell-Smith NJ, Chan JC-Y, et al. Reactive and infective dermatoses associated with adult-onset immunodeficiency due to antiinterferon-gamma autoantibody: Sweet's syndrome and beyond. Dermatology. 2013;226(2):157-66. https://doi.org/10.1159/000347112.

26. Browne SK, Burbelo PD, Chetchotisakd P, et al. Adult-onset immunodeficiency in Thailand and Taiwan. N Engl J Med. 2012;367(8):72534. https://doi.org/10.1056/NEJMoa1111160.

27. Orange JS, Hossny EM, Weiler CR, et al. Use of intravenous immunoglobulin in human disease: a review of evidence by members of the primary 
immunodeficiency Committee of the American Academy of allergy, asthma and immunology. J Allergy Clin Immunol. 2006;117(4 Suppl):S525-53. https://doi.org/10.1016/j.jaci.2006.01.015.

28. Koya T, Tsubata C, Kagamu H, et al. Anti-interferon- $\gamma$ autoantibody in a patient with disseminated <emphasis type $=$ "italic" $>$ Mycobacterium avium $</$ emphasis> complex. J Infect Chemother. 2009;15(2):118-22. https://doi.org/ 10.1007/s10156-008-0662-8

29. Kampitak T, Suwanpimolkul G, Browne S, Suankratay C. Anti-interferon- $y$ autoantibody and opportunistic infections: case series and review of the literature. Infection. 2011;39(1):65-71. https://doi.org/10.1007/s15010-010-0067-3.

\section{Publisher's Note}

Springer Nature remains neutral with regard to jurisdictional claims in published maps and institutional affiliations.

Ready to submit your research? Choose BMC and benefit from:

- fast, convenient online submission

- thorough peer review by experienced researchers in your field

- rapid publication on acceptance

- support for research data, including large and complex data types

- gold Open Access which fosters wider collaboration and increased citations

- maximum visibility for your research: over $100 \mathrm{M}$ website views per year

At $\mathrm{BMC}$, research is always in progress.

Learn more biomedcentral.com/submissions 